\title{
$11-27$
}

\section{"PALABRAS QUE VAN A DAR AL RÍO DE UNA POESÍA INÚTIL". UNA APROXIMACIÓN A LA POÉTICA DE JAIME HUENÚN A PARTIR DE PUERTO TRAKL ${ }^{1}$}

"Words that end up in a river of useless poetry".

An approach to the poetics of Jaime Huenún, as seen through Puerto Trakl

Sergio Mansilla*

Resumen

A partir de la lectura del poemario Puerto Trakl se discuten algunos aspectos claves de la poética de Jaime Huenún en lo relativo a las traducciones culturales de su escritura mestiza. La propuesta literaria de Huenún avanza en la dirección de construir una moderna poética mapuche huilliche que hace confluir modos de textualización que provienen tanto de discursividades indígenas como no indígenas, descentrándolas. En Puerto Trakl lo que se descentra son precisamente las discursividades de lo más canónico de la poesía moderna internacional.

Palabras clave: Poesía chilena, poesía indígena, poesía mestiza, modernidad intercultural, poética mapuche huilliche.

Abstract

Beginning with a reading of the collection Puerto Trakl, we discuss some key aspects of Jaime Huenún's poetics, related to the cultural translations of his mestizo writing. Huenún's literary proposal advances in the direction of constructing a modern mapuche-huilliche poetics, which makes modes of textualization that originate from indigenous and non-indigenous discursivities merge, descentralizing them in the process. In Puerto Trakl, what descenters are precisely the discursivities of the most canonic of modern international poetry.

Key words: Chilean poetry, indigenous poetry, mestizo poetry, intercultural modernity, mapuche huilliche poetics.

\section{PRESENTACIÓN}

Jaime Luis Huenún Villa (1967, Valdivia, Chile) tal vez sea, hoy por hoy, el poeta chileno de origen indígena más influyente en la línea de aquella poesía que reivindica la memoria y la identidad indígena-mestiza, problematizando sobre la base de este compromiso ético el estatuto mismo de la modernidad y sus registros poéticos más depurados. Se trata de un asunto de impacto cultural (y político, estimo) no menor si, como en este caso, ocurre en un país llamado Chile, cuyas elites económicas y políticas han tendido siempre a creer y hacer creer que Chile es tan blanco, tan "europeo" que la presencia indígena es poco menos que un

\footnotetext{
${ }^{1}$ Este trabajo forma parte de la ejecución del Proyecto Fondecyt $\mathrm{N}^{\circ} 1095026$.
} 
accidente racial. $^{2}$ De obra breve hasta ahora (sólo ha publicado dos libros que sumados no superan las 100 páginas, Ceremonias en 1999 y Puerto Trakl en 2001, a lo que se adicionan algunos poemas dispersos), la presencia de Huenún se hace notar en dos ámbitos interconectados: uno en el campo del activismo poéticopolítico que, en su caso, se concreta en un persistente trabajo por dar a conocer a lectores chilenos y extranjeros los varios registros de la poesía de autores de origen indígena, sobre todo de origen mapuche y mapuche huilliche. ${ }^{3}$ Tanto en las antologías de las que ha sido editor o compilador, así como en textos varios de carácter reflexivo (ensayos, discursos, entrevistas), no pierde oportunidad de enfatizar que la poesía mapuche ha de leerse a partir de claves históricas, políticas, culturales y de sensibilidad situadas en el contexto específico de la lucha por el reconocimiento que las comunidades mapuche chilenas vienen protagonizando sistemáticamente desde los años de 1980 hasta ahora.

La apuesta de Huenún en este ámbito es presentar la poesía indígena moderna de Chile no como una cuestión de simple continuidad o discontinuidad de paradigmas de escritura poética explicables y comprensibles en el solo dominio de la textualidad literaria. Su modo de ser poeta-lector indígena mestizo pasa por un persistente ejercicio de religamiento de la escritura poética con la lucha cultural-política por construir una cierta ontología indígena moderna que no se agote, como a veces ocurre, en una paralizante insistencia en imágenes elegíacas de victimización. Arremete, pues, contra la idea de que el dominio de la literatura sería una esfera de acción autónoma que despliega una historia

\footnotetext{
${ }^{2}$ En los últimos 20 años las comunidades indígenas, particularmente la mapuche, han instalado una agenda de reivindicaciones culturales, territoriales y políticas que sólo de manera muy parcial ha sido atendida por el Estado chileno. La creciente criminalización de los movimientos de protesta indígena es parte de la incapacidad de las elites chilenas $-\mathrm{y}$ de su aparato político e institucional oficial - de resolver un problema cuya solución no pasa por el asistencialismo ni por simples políticas de subvención de "proyectos productivos".

${ }^{3}$ Huenún ha editado hasta el momento tres antologías importantes: La memoria iluminada. poesía mapuche contemporánea, edición bilingüe mapuchezëngun-castellano publicada en Málaga; 20 poetas mapuche contemporáneos, publicada en Santiago de Chile; Antología de la poesía indígena latinoamericana, publicada igualmente en Santiago de Chile y que incluye a 21 poetas chilenos, además de poetas de Perú, México, Ecuador y Argentina, cuyos textos aparecen en español y en lenguas indígenas de los respectivos países. Ha sido, además, director de la revista Pewma, Literatura y Arte. En Chile existen varios grupos étnicos, pero el más numeroso es el mapuche (gente de la tierra). Se denomina mapuche huilliche a una rama del pueblo mapuche que centralmente ocupó lo que hoy son las provincias de Valdivia, Ranco, Osorno y parte de Llanquihue, lo que conformaba la Fütawillimapu o grandes tierras del sur. Literalmente huilliche significa gente del sur, siempre desde la perspectiva de los mapuche instalados inmediatamente al norte de la provincia de Valdivia y que ocupaban un territorio que comprende las actuales regiones de la Araucanía por el sur y del Bío-Bío por el norte. Los antiguos territorios mapuche fueron objeto de violenta ocupación militar de parte del Estado chileno en el siglo XIX y, junto con los territorios hulliche, entregados luego a colonos chilenos y extranjeros, principalmente alemanes, quienes convirtieron las mejores tierras en campos agrícolas y ganaderos a escala industrial. Se formó una clase terrateniente en el sur de Chile a expensas del despojo de tierras de que fueron víctimas los indígenas.
} 
de mutaciones textuales y discursivas engañosamente autocontenidas en el exclusivo terreno de las variaciones de los estilos y temas.

El segundo ámbito de presencia "fuerte" de Huenún arranca de la naturaleza de su propio proyecto escritural: éste no se reduce a ser simplemente el horizonte regulador de su práctica personal de escribir versos. Se trata, en rigor, de un proyecto intelectual-político orientado a conformar la poética de un proyecto de modernidad indígena (y no sólo estético) aún no del todo formalizado, en proceso de construcción. De manera que la práctica de escribir poesía y de pensar sobre ella es, en su caso, una práctica crítica sobre el sujeto moderno - indígena, mestizo, no indígena- puesto éste en la perspectiva de ser comprendido y representado en sus itinerancias identitarias que lo llevan al encuentro y/o desencuentro consigo mismo y con la alteridad. Así, la clásica y simplista delimitación nosotros vs. otros, en la que el pronombre "nosotros" alude a los occidentales "civilizados", y el adjetivo pronominalizado "otros" a esos eternos "bárbaros" nunca aptos para ser sujetos propiamente de la modernidad, quedaría, si no superada, por lo menos bien escarmenada bajo la lupa del escrutinio crítico.

Por cierto que ha corrido mucha agua bajo el puente desde los tiempos en que Sarmiento entendía el drama de lo que hoy llamamos América Latina como un desgarrador conflicto entre civilización y barbarie; pero no es menos cierto que el desmontaje de esquemas binarios reductores, que tienden a crear abismos entre victimarios y víctimas ayudando a perpetuar así el colonialismo (y postcolonialismo) del Nuevo Mundo, es todavía una tarea en curso. El ingreso de poetas de origen indígena al canon de la modernidad literaria, y no sólo como voces "otras" atendibles por su singularidad "exótica" o por el estatus sacrificial que les daría el sufrimiento histórico del que han sido víctimas, sea acaso uno de los procesos culturales y literarios más profundos, complejos y subversivos que viven las sociedades latinoamericanas de hoy. En cualquier caso, de la chilena sí que lo es sin ninguna duda.

\section{POESÍA MODERNA Y POÉTICA DEL MESTIZAJE}

De Puerto Trakl, Hugo Carrasco ha afirmado enfáticamente:

Aquí ya no se encuentra presente el mundo indígena, ni las problemáticas del mestizaje, cultura propia, interculturalidad, lenguaje híbrido, heterogeneidad, sincretismo, dualidad, etc. Por el contrario, es una poesía de características universales y clásicas, en la tradición de la poesía occidental, en la voz de un poeta mapuche-huilliche que se reconoce como tal, pero también incorpora la cultura formal, su saber poético, su lengua castellana y sus lecturas (2005:62).

Para sustentar sus juicios, Carrasco alude a una "entrevista directa" en la que Huenún sostiene que Puerto Trakl se inscribe dentro de propósitos estéticos que, al menos en apariencia, lo separarían de la línea escritural de su primer libro Ceremonias, volumen 
que, a primera vista, se manifiesta como contenedor de una poesía depuradamente etnocultural. En Puerto Trakl, en cambio, la intencionalidad estética, según Huenún mismo, en la entrevista ya aludida, ${ }^{4}$ avanza en la dirección de

crear un mundo poético autónomo basado en temas tales como el exilio, la errancia, el desarraigo, el viaje a ciegas por el laberinto del poema, la orfandad de la poesía tanto en el contexto de la realidad contemporánea como en el lenguaje mismo [...] La lengua poética se hace cargo de sus límites, abandonando discursos hegemónicos, mesiánicos, salvacionistas (64).

Reacio siempre a dejar que a su poesía se la rotule como "poesía étnica" sin más, Huenún proclama su "rebeldía frente a rótulos, a las marcas, a esos timbres que se nos asignan" ("Me rebelo contra el rótulo...", 2010); rebeldía que no se explica sólo por un ánimo libertario de tipo romántico individualista, sino, sobre todo, por la profunda fidelidad y lealtad a sus orígenes - un motivo fundamental en su escritura - tanto que su yo lírico se subsume, a menudo, en voces múltiples, entrecruzadas, que transitan en permanente itinerancia por los vastos territorios semióticos del mundo lírico mestizo de Huenún ${ }^{5}$

No tuve - nos dice el poeta - la experiencia comunitaria, en el sentido de vivir en la ruralidad, pero sí tuve la experiencia de imaginarios indígenas, que cotidianamente llegaban a mi casa, se expresaban en mi hogar y poco a poco fui construyendo una memoria particular [...] De alguna manera no se tiene lo que otros poetas mapuches sí pueden decir que tienen, pero se tiene la necesidad de crear un imaginario para suplir la carencia ("Me rebelo contra el rótulo...").

Huenún se ve, pues, escribiendo en los extramuros de su propia indigenidad. $\mathrm{Y}$ es en este contexto identitario en el que escribe Puerto Trakl: "un ademán literario - nos dirá el propio autor - que quería decir que un poeta de origen mapuche perfectamente podía escribir un libro de poesía universal, instalarse en otro discurso y coordenadas literarias y no sólo hacer alusión a su origen étnico" ("Me rebelo contra el rótulo..."). A la luz de declaraciones como éstas, pareciera razonable pensar que Puerto Trakl representa el lado no étnico de la poesía de Huenún, su lado "universal” y "clásico"; literario en el sentido más canónico del

\footnotetext{
${ }^{4} \mathrm{H}$. Carrasco no indica referencias de origen de la entrevista a la que alude y cita. Se puede deducir, sin embargo, que habría sido concedida al propio Hugo Carrasco en fecha y lugar que no se señalan.

${ }^{5}$ Huenún, a diferencia, por ejemplo, de Neruda que construye un yo poético hiperbólico que se siente llamado a hablar, con "lo profético que hay en mí" (Cfr. "Arte poética", en Residencia en la tierra), por los que no tienen voz (el pueblo, los elementos, las cosas de uso cotidiano), trabaja la idea de una subjetividad invisible, que ojalá llegase a estar absolutamente constituida por las voces de esos otros con los que el poeta se siente solidario: "escribo también para dar cuenta de mi propia realidad, de mis propia crisis o armonías; pero, finalmente, todo lo que pueda escribir busca la posibilidad de que el poeta desaparezca de la escena y quede el lector individual o colectivo ahí enfrentado a su propio lenguaje" (Huenún, entrevistado por Monserrat Martorell, 2010).
} 
término, lejos de la urgencia de escribir con aquellas memorias culturales que conforman la subjetividad de un yo subalterno, territorial, etnoculturalmente etiquetado como "mapuche huilliche". En efecto, a diferencia de Ceremonias, Puerto Trakl se nos presenta como escritura desterritorializada que dialoga con las discursividades de poetas situados en la centralidad del canon de la poesía moderna internacional, europea principalmente. Hablamos de Trakl desde luego, de Rilke, Valery, Celan, Eliot, Melville; también de Jorge Teillier, Álvaro Mutis, entre otros, cuya presencia en Puerto Trakl evidenciaría la emergencia de un mundo literario autónomo y universal liberado de las localías que comportan rasgos de hibridismo o de interculturalidad como los que, sí, estarían operando en Ceremonias.

Semejante modo de ver la producción poética de Huenún se sustenta en la constatación de las evidentes diferencias temáticas y referenciales entre Ceremonias y Puerto Trakl. Mientras el primer volumen exhibe reiteradas alusiones al mundo mapuche huilliche del territorio de la Fütawillimapu, con un fuerte énfasis en la tematización de las genealogías familiares y de la comunidad, el segundo se nos manifiesta como una especie de viaje iniciático de un sujeto lírico cuya voz se entremezcla con otras voces que acontecen en un simbólico, fantasmagórico y radicalmente literaturizado locus denominado Puerto Trakl, en el que la decadencia y la inanidad juntas son la norma. Se trata, no obstante, de diferencias de superficie.

Sostengo que Puerto Trakl, precisamente por obliterar el factor etnocultural -no obstante ser su autor un poeta que desde sus primeros textos, cuando aún era adolescente a mediados de los años de 1980, ha hecho de la etnicidad y de las memorias culturales la viga maestra de su escritura - se puede ver como signo de ampliación y complejización del diálogo intercultural, situándose ahora en el terreno de la poesía moderna internacional. Estamos efectivamente ante una escritura que arremete contra el estereotipo de que un poeta que reivindica orígenes indígenas no haría sino escribir sobre "cosas de indios". Pero, por lo mismo, el poemario viene a ser la materialización de una de las facetas del proyecto intelectual al que se halla abocado Huenún: elaborar una poética del mestizaje mapuche huilliche-chileno, "una especie de poesía nacional mapuche" —en palabras del propio Huenún-6 "glocalmente" situada, cuyas textualidades puedan estratégicamente transitar desde

\footnotetext{
${ }^{6}$ Huenún formula la noción de "poesía nacional mapuche" a propósito de la publicación de la antología 20 poetas mapuches contemporáneos, de la cual es editor. Si bien no la formula para describir su propia poesía, resulta claro que su manera de leer a otros poetas mapuches actuales (toda antología comporta una decisión de lectura) forma parte de su modo de escribir en la medida en que éste, a su vez, es la expresión en formato texto de un cierto modo de leer (y de escribir) el deteriorado libro de la memoria del pueblo indígena. En el prólogo de La memoria iluminada, Huenún aclara: "esta antología no pretende sino ser sino un libro dialogante, el registro abierto y quizás fragmentado de los recuerdos, paisajes, tragedias y cantos de un grupo humano que busca autodeterminarse en tiempos adversos y a la vez promisorios" (2007:22). Ver, también "Me rebelo contra el rótulo..." (2010).
} 
zonas de significación que provienen en un sentido bien riguroso de los mundos indígenas mapuche huilliche, radicalmente "otras" en relación con la cultura occidental, hasta aquellas zonas que conforman las tramas textuales de lo más canónico de la poesía moderna. Con la idea de "tránsito estratégico" me refiero no a un vagabundeo entre culturas y/o entre textualidades varias: se trata tanto de una empresa de introspectivo desciframiento ontológico y existencial del sujeto mestizo tanto como de superación liberadora de los límites que imponen los estereotipos puristas que, en el terreno de una relación intercultural desigual y colonizante, empujan a que los sujetos se atrincheren en espacios pre-construidos que terminan refrendando las estructuras y relaciones de dominación. Huenún es muy claro al respecto

[Escribo] para recuperar la memoria de mi familia, de mi comunidad. Escribo para intentar, mediante la poesía, mediante el lenguaje lírico, reconstituir espacios de diálogo. No solamente entre un sector y otro, el sector mapuche y chileno, sino que reconstituir un diálogo con el sujeto mismo, el sujeto indígena dañado consigo mismo, $y$, tal vez, el sujeto chileno dañado. En el poema no habla el poeta (Martorell, entrevista, 2010).

La tarea reconstitutiva que Huenún le asigna a su poesía nos provee de una clave de capital importancia para leer Puerto Trakl desde una mirada que permita ver el poemario no sólo como una especie de salto a temas "universales" (como si el amor, la muerte, temas centrales en Ceremonias, no fuesen ya "universales"), en apariencia dando la espalda a los ya consabidos tópicos étnicos y culturales asociados a territorio, memoria, reivindicaciones identitarias, interculturalidad. A mi parecer, ambos libros no debieran verse sino como parte de un mismo proyecto escritural: atestiguar/construir en y por la escritura literaria, que incluye poesía y textos reflexivos de diversa factura, y a través del activismo literario del autor, una identidad cultural-poética concebida como itinerancia de los sujetos, de desciframiento, descentramiento de estereotipos y categorías etnoculturales. Avanzar, en suma, una cierta forma de mestizaje de imaginación y memoria cuya expresión de escritura dé cuenta precisamente de las singularidades mestizas, las cuales, por otra parte, han de emerger del desciframiento mismo del yo y de sus entornos semióticos. Hablamos de un quehacer introspectivo - que por cierto desborda lo psicológico - siempre en curso, siempre parcial, siempre sustentado en la experiencia y no en la sola teorética del sujeto y sus diversidades.

Nueve años antes de la entrevista concedida a Martorell, en otra entrevista concedida esta vez a Alberto Ganderats, en 1999 (justamente con motivo de la publicación de Ceremonias), Huenún se distancia del rótulo de poeta huilliche si es que éste implica arrojar a la penumbra el lado no indígena de su origen

La verdad es que no puedo sentirme sino mitad huilliche, mitad huinca, porque mi madre no es indígena. Sin embargo, desde los diecinueve años estoy descifrando mi pasado, buscando las raíces. Claro que ante todo, soy 
poeta $[\ldots]$ un hombre que hace preguntas y no logra responderlas nunca, salvo en detalles (en línea).

"Ante todo, soy poeta". Léase esta declaración de identidad como el imperativo ético de erigir una escritura que, de ningún modo, renuncie a atestiguar sus dos mitades. El trabajo de la memoria poética acontecerá no como nostalgia, no como lamento por un pasado presuntamente pleno, sino como homenaje e inquisición en las raíces dobles que alimentan su imaginación y memoria y que lo constituyen como sujeto mestizo comprometido con la magna tarea de escribir poesía nacional mapuche huilliche moderna, de pensar la interculturalidad como un diálogo desmitificador del sujeto consigo mismo y con el otro. Entendamos que el "sí mismo" no se lo concibe como cerrazón egocéntrica, sino al revés: es el espacio donde los otros, sin importar de qué tronco cultural provengan, hallan sitio para morar y prestar - aunque sea a retazos - voz al poeta.

\section{PUERTO TRAKL Y LOS LUGARES QUE NO SON LUGARES}

Gruesamente descrito, Puerto Trakl es la alegoría de una poesía que se arma (en el doble sentido de ensamblarse y de proveerse de armas) contra la precariedad del lenguaje y de la poesía en un mundo en que el tiempo y la historia han perdido eficacia - se han vuelto, diríamos, una rueda que gira interminablemente sobre su desgastado eje-, en el que las metáforas carecen de genuina importancia y los poetas, con suerte, se consumen en la indiferencia de tugurios en los que unas pocas monedas valen más que cualquier brillante escritura. Si ni siquiera se puede morir en Puerto Trakl, aunque, al mismo tiempo, de un modo torvo y misterioso sus habitantes no hacen sino morir todo el tiempo. El lugar llamado Puerto Trakl es, pues, la "tierra baldía" de la poesía moderna: ahí la decadencia se vuelve poesía y la poesía no comunica sino la opresiva soledad del hablante. Perspicazmente atento al drama del poeta moderno arrojado a las callejas marginales de una modernidad que ha hecho de la poesía y del poeta un residuo del pasado, una mercancía desechable o a lo más un adorno prescindible, Huenún no cesa de ajustar cuentas con ese mundo fantasmal y derrotado. El poeta moderno, tal como el autor lo dibuja en Puerto Trakl, al menos en lo tocante a su autoclausura existencial y escritural, se halla en un intríngulis de difícil o acaso imposible solución: autoconvocado a escribir poesía —el "poema feliz que ojalá fuera éste", diría Lihn — ${ }^{7}$ para un mundo en el que la poesía se ha tornado un bien degradado (que, con mucha fortuna, sirve para financiar el embriagador vino del aturdimiento ante un futuro sin futuro) al poeta no le queda sino hundirse en una mezcla de autodestrucción, escepticismo radical y cinismo o, en su defecto, emigrar en busca de otros lugares en los que la palabra mayor de la poesía halle terreno fértil para cantar, al fin, una épica de victoria.

\footnotetext{
${ }^{7}$ Cfr., el poema "Bosque" de Enrique Lihn, originalmente publicado en Antología al azar en 1981.
} 
Vicente Bernaschina lee Puerto Trakl como un poema único que "relata el descenso del poeta a un puerto imaginario y decadente en el que busca, cada vez con más desencanto, encontrar el modo y la audiencia para contar su travesía. Sin embargo, allí sólo encuentra viajeros mudos y borrachos en su abandono" (en línea). Al entender de Bernaschina, el motivo estructurante principal del poema-libro es la experiencia del trauma y el exilio: "un motivo que hoy ya parece un lugar común a la hora de hablar de la experiencia del poeta moderno" (en línea). Bernaschina estima, sin embargo, que Huenún elabora un segundo motivo que toma fuerza a medida que se acerca el final del poema: "la voz toma conciencia de que existen otras cosas fuera del discurso que constituye el puerto y la voz termina por reconocer las condiciones de puerto ficticio en el que está y la necesidad de abandonarlo" (en línea).

Las observaciones de Bernaschina hacen sistema con las tesis que el propio Huenún defiende sobre la naturaleza y la función restituyente que la poesía cumpliría en cualquier sociedad

La poesía es una aventura azarosa y difícil, pero necesaria, que ha estado siempre presente en la historia de todas las culturas. Y en medio de la tragedia, de las contradicciones, de las angustias humanas, la poesía ha intentado convertirse en el elemento que le permita al hombre mantenerse en pie y prevalecer en medio de la banalidad, la rutina, el sinsentido y el poder todavía incontrarrestable de la muerte [...] Si bien en los últimos siglos la poesía se ha apartado de lo estrictamente religioso o ceremonial y los poetas se han convertido en sujetos laicos, en sujetos civiles, en personas que deben lidiar con el lenguaje y con una serie de variables culturales de su tiempo, la poesía no ha dejado de tener una ligazón con lo más puramente religioso o numinoso del ser humano. La poesía es, en este sentido, el canto que el hombre todavía no logra entender o descifrar completamente, el canto a través del cual el universo le habla y a través del cual los espíritus de la memoria están tratando de comunicarse (Góngora y Picón, entrevista, 2010).

Como ya he adelantado, el poemario (o poema, según se mire) Puerto Trakl es una depurada alegoría poética de la miseria de la poesía moderna; alegoría que toma la forma de un "puerto" imaginario situado en vagas geografías que podrían ser del hemisferio norte (se alude a la estrella polar en un par de ocasiones); puerto miserable, decadente, cuyos habitantes no pueden sino producir discursos decadentes y miserables que no hallan destinatarios o que hallándolos no alcanzan más recepción que la indiferencia y el olvido. Pero, al mismo tiempo, el libro dibuja un sujeto lírico — capitán Melville, aunque no sea ése su nombre (39) — empeñado en escribir en su "bitácora mercante" (y comunicar), aún al precio de su propia aniquilación, los "dictados de su corazón": papeles que, arrojados más tarde a "las acequias / anegadas por los desperdicios / y la lluvia" (41), crean, por el intolerable fracaso que representa su indolente destrucción, las condiciones para romper esas opresivas ficciones y abandonar Puerto Trakl, retornando "sin dinero, sin amigos, sin reputación / a sus 
antiguos días". "Los tugurios donde beben poetas y pescadores / quedan para siempre atrás" (53), son versos finales del libro que remachan la idea de que Puerto Trakl no es, no puede ser, no debe ser, el destino de los poetas y de la poesía.

Para el hablante, capitán de un vago navío que ha navegado la soledad de mares neblinosos, Puerto Trakl es un espejismo que proyecta una promesa de descanso, de refugio, de espacio para la conversación. Poseedor de las experiencias de la travesía, el sujeto hablante siente la necesidad de recrearlas con la palabra y comunicarlas en un gesto dialógico de intercambio semiótico que lo arranque, por un lado, de la mudez que lo constituye, y, por otro, convoque a sus eventuales oyentes a compartir las memorias de las travesías y generar, así, una forma de comunidad unida en torno al relato

Bajé a Puerto Trakl entre neblinas.

Buscaba el bar de la buena suerte para charlar sobre la travesía.

Pero todos miraban la estrella polar en sus copas, mudos como el mar frente a una isla desierta (5).

No hay, sin embargo, audiencia para el relato de esta vida ni de ninguna otra ¿A quién podría importarle el destino de un recién llegado que arriba precisamente a un mundo sin destino, ruinoso, indolente, autodestructivo, pero en el que tampoco se puede morir de verdad, permaneciendo los sujetos en un estado de perpetua errancia, carentes de afectos y sin más desplazamientos que el que acontece en callejas inmundas mil veces recorridas? Y lo que hubiera podido ser la charla sobre la travesía se convierte en el tortuoso relato de un "capitán" poeta errante enfrentado a su propio fracaso existencial y discursivo; algo que se conjurará sólo asumiendo que, ante el fracaso, no queda sino continuar el viaje hacia "otra tierra [...] mejor que esta colina / mejor que esta bahía donde muere la luz" (49). Y aunque el sujeto lírico diga que le asquea profetizar (11), al fin no hace sino prefigurar y anunciar la otredad de ese mundo agónico en la que, presumiblemente, la poesía sí cumpliría con éxito la función de construir comunitarismo por la palabra. Pero esa otra tierra deseada y, podría decirse, prometida por la poesía (“donde el pan sepa a pan”, 49) no sería sino una suerte de imperativo ético que arranca de la necesidad imborrable de escribir y construir (o de ayudar a construir con la poesía) afectos reales, significaciones constituyentes de una verdadera historia de emancipación por la que el sujeto se libera de la espuria condición de poeta afectado de una decadencia sin remedio mientras permanezca en el baldío Puerto Trakl.

Hugo Carrasco estima que "el mundo creado [en Puerto Trakl] es totalmente distinto a los anteriores" (62, itálicas mías). ${ }^{8}$ Este juicio, a mi entender, se deriva del hecho de leer Ceremonias, y su texto antecedente, de un modo reductor: al ser leídos como documentos poéticos situados exclusivamente en la orilla étnica de la identidad

\footnotetext{
${ }^{8}$ Con la expresión "a los anteriores", Carrasco se refiere a Ceremonias y a su texto que lo antecede: Sudario (1986 - 1993), que circuló en su momento en versión fotocopiada.
} 
mapuche huilliche de Huenún, en estos poemarios, a la inversa de Puerto Trakl, los referentes mapuche huilliche copan absolutamente lo que podríamos llamar el campo de representación de lo real. ${ }^{9}$ Tal mirada, sin embargo, no considera que Ceremonias es también una escritura metapoética que, en tanto tal, desnuda los límites representacionales de una poesía indígena escrita en la lengua de los conquistadores, la que por obra de la violencia colonizadora se ha vuelto, a la larga, lengua de los conquistados: ¿Con qué retórica entonces ha de hablar el subalterno de sí mismo, recuperar/construir una identidad alterna, genuinamente liberadora, si para hacerlo dispone de un idioma que estuvo, en su momento, al servicio de la laminación de la alteridad llegando a ser, tal vez, el más poderoso instrumento de subalternización y de supresión de memoria indígena? ${ }^{10} \mathrm{Y}$ todavía más: ¿Cómo puede sostener Huenún el proyecto de construir una poesía mapuche moderna, con arraigo etnonacionalista, que resguarda las tradiciones identitarias territorializadas - pero que, al mismo tiempo, las modifica - que no pase por incorporar dialógicamente referentes de la mejor poesía que la modernidad occidental ha podido producir? Bien sabemos que la modernidad, en su dimensión homogeneizante e imperialista, ha trabajado a favor de la borradura radical de los mundos indígenas. Pero la modernidad comporta, también, un modo revolucionariamente crítico de construir morada vital.

La propuesta literaria de Huenún avanza, justamente, en la dirección de construir una cierta poética moderna (mapuche huilliche-chilena-hispanoamericana) que hace confluir modos de textualización que provienen tanto de discursividades indígenas como no indígenas. Las primeras le vienen al poeta por filiación — dado su origen indígena por línea paterna - pero, también, por afiliación sobre todo cuando las discursividades indígenas son cultural y estéticamente traducidas, con un alto grado de elaboración, a poesía escrita, a pensamiento ensayístico, a activismo literario, lo que, por otra parte, hace evidente el carácter político, en el mejor sentido del término, del proyecto intelectual de Huenún. ${ }^{11}$ Las segundas, igualmente le llegan por filiación dada su condición de mestizo, por línea materna y por haber sido sujeto del sistema de educación formal chileno que contribuyó decisivamente a prepararlo para acceder al

\footnotetext{
${ }^{9}$ Hablamos de referentes mapuche huilliche movilizados como materiales simbólicos con los que se construye una reivindicación de las genealogías familiares y comunitarias del poeta así como una poderosa denuncia de las injusticias y atropellos de que ha sido víctima la comunidad indígena desde los tiempos de la conquista hasta ahora. Me he referido con algún detalle sobre esto en el prólogo de Ceremonias.

${ }^{10}$ Rodrigo Rojas, haciendo suya una idea del propio Huenún, sostiene que la lengua de Huenún es la champurria, "palabra que designa al mestizo desde una enunciación huilliche [...] Es una forma de vivir, de hablar, de construir en sí mismo, en su visión de mundo, un espacio en el que confluyen culturas, lenguas y diferentes - y a menudo contrapuestos - relatos históricos" (2009:66). La definición de champurria de Rojas encaja bien con Ceremonias; aplicada a Puerto Trakl resulta forzada y poco esclarecedora en mi opinión. De cualquier modo, las tesis de Rojas invitan a una reflexión fina sobre los múltiples modos de ser del mestizaje.

${ }^{11}$ Para las nociones de "filiación" y "afiliación" ver Edward Said, principalmente la "Introducción” a El mundo, el texto y el crítico (2004).
} 
campo de las letras. En una fase de complejidad escritural superior, tal filiación muta en afiliación en la medida en que la asunción de discursividades no indígenas toma la forma de un sostenido proyecto intelectual, que es, a la vez, cultural-político; de apropiación de esos discursos para efectos de tensar con ellos la tradición de la oralidad indígena y así arrancarle a ésta aquellas significaciones poéticas que den paso a la elaboración de una cierta modernidad literaria indígena; apropiación que es, también, desapropiación y descentramiento de las discursividades no indígenas que pasan, entonces, a ser materiales alimentadores de una poesía mestiza que inaugura nuevos registros discursivos en el campo de la poesía chilena. Puerto Trakl es, qué duda cabe, un homenaje a la poesía de Georg Trakl, a esos mundos crepusculares y extraños que abundan en los versos del poeta austriaco; pero, en la lógica antes descrita, es, al mismo tiempo, un modo de hacer que esta poesía se vea como una sospechosa estetización de mundos clausurados, incompatibles con la necesidad de llegar a otra tierra "donde el pan sepa a pan". ${ }^{12}$

El proyecto poético-político de Huenún no se reduce, sin embargo, a la simple confluencia de discursividades y/o de fuentes textuales varias en su escritura. No es cuestión sólo de extraer los beneficios retóricos de los diversos registros discursivos que sustentan la escritura de Huenún sin que éstos últimos no sean afectados en su, digamos, estatuto de verdad de uso. Al contrario, la poesía de Huenún puede ser descrita, en este aspecto, como una forma de escritura que se sostiene en el esfuerzo constante de tensar las discursividades varias que la constituyen haciendo visible tanto las aporías de éstas, sus contradicciones, sus puntos ciegos, sus lugares dañados, como la potencia reveladora de realidad de estas zonas pantanosas de los discursos, conformando así una retórica que hace justicia a un hablar polivalente, heterogéneo, precisamente porque la poesía de Huenún negocia con los flujos de traducción entre formaciones culturales diversas.

Quisiera proponer la tesis de que el nütram, práctica dialógica proveniente de la oralidad indígena mapuche, ampliada y reconfigurada como un vasto relatodiálogo textual y cultural, es la base de la estrategia de escritura poética de Jaime

${ }^{12}$ Como el lector ya habrá reparado, Puerto Trakl es el nombre de un puerto imaginario, decadente, en el que los poetas y la poesía son una mercancía destinada al abandono, al cultivo sistemático de la marginalidad y autodestrucción cuando más. Este locus - cuyo nombre da título al libro - se conforma a partir de un modo de leer la poesía de Georg Trakl, y seguramente el destino vital de este poeta austriaco (recordemos que era drogadicto y alcohólico; se suicida en 1914, en el hospital siquiátrico de Cracovia, con una sobredosis de cocaína después de haber participado como teniente de sanidad en el frente de guerra), modo de leer que pone en evidencia la clausura definitiva de toda posibilidad de genuina felicidad humana; poesía que, por lo mismo, se vuelve documento de una cultura, la occidental, que para la sensibilidad de Trakl ha cruzado ya el umbral de su propia extinción. La apuesta de Huenún es, justamente, hallar una salida a este sombrío mundo, asumiendo, a la vez, que su propio mundo, indígena, mestizo, está poblado de sujetos dañados tanto como el mundo que hallamos en la poesía de Georg Trakl. 
Huenún. ${ }^{13}$ Mas, esto no acontece como una simple transcripción más o menos adaptada a las convenciones del poema en verso libre del modo oral del nütram. Huenún lo despliega como una gran "conversa" heterogénea, intercultural y polidiscursiva, siempre en curso, siempre abierta a nuevas hablas, que hace suya voces varias, de vivos y de muertos, de indígenas y de blancos, de chilenos y extranjeros, de grandes poetas universales y de gente iletrada, de cronistas e historiadores de la cultura dominante y de anónimos narradores de memorias orales. Voces varias que denotan una gama amplia de sujetos y de situaciones (o mejor, de sujetos en situación) movilizados para conformar una poesía comprometida con la insubordinación de las memorias culturales y, por lo mismo, con el desmontaje y superación de la subalternidad radical. Se trata, en definitiva, de un proceso cultural-político que en el terreno de la poesía, por el afán de Huenún de hallar/construir una palabra poética liberadora vía desciframiento de las raíces identitarias (que en él, como sabemos, no son sólo indígenas), deviene escritura a contracorriente de la estetización de la decadencia y el pesimismo entrópico que caracteriza a buena parte de la poesía moderna.

Ceremonias y Puerto Trakl, a los que hay que sumar sus textos reflexivos, son manifestaciones concretas de un proyecto en curso cuyos resultados finales (si es que se puede hablar así para el caso de la escritura literaria) están aún por verse; pero la sola puesta en marcha de esta empresa textual es ya un descentramiento de las discursividades nutricias de la escritura de Huenún: no se acude a ellas como mera fuente de referencias culturales, sino que éstas ingresan a la poesía de Huenún en su condición de proferimientos "otros" exigidos al máximo, tanto que el poeta, en una atmósfera de dolor vallejiano, les descoyunta sus articulaciones haciéndolos parte de una metafísica mestiza que busca restituir el diálogo de sujetos dañados. Son voces que atestiguan, en parte, su propia imposibilidad de plenitud expresiva y comunicativa; en parte, la verdad histórica, política y existencial que portan; ambivalencia que emerge del hecho de ser desplazadas de su nicho semiótico de origen al nicho semiótico de una poesía comprometida, en lo ético, con la restitución de la igualdad y la justicia, con la democracia de la memoria, pero consciente de que las significaciones que harían exitoso este compromiso es un asunto no concluido en absoluto. Al revés: el trabajo de construirlas es el verdadero - y acaso imposible - objetivo de una escritura-diálogo concebida como devenir rigurosamente historizado.

Desde esta perspectiva, Puerto Trakl — que se estructura sobre el clásico motivo del viaje - cabe leerlo como una implacable crítica a aquel modo moderno de producir y vivir la poesía en el que la seductora belleza de la decadencia y la

\footnotetext{
${ }^{13}$ La expansión semántica del sustantivo nütram la propongo a partir de la definición que de éste formula el propio Huenún: "la conversación mapuche que utiliza retazos de mitos, recetas medicinales e historias de parientes y vecinos vivos y difuntos" (Ceremonias, 1999:47). Para mayor abundamiento sobre la noción de nütram remito al trabajo de María Angélica Relmuan Álvarez (1997).
} 
muerte crepusculares parecieran ser la norma a la hora de poetizar la realidad; realidad que aquí toma la forma, como ya aclaramos, de un fantasmal locus literario llamado Puerto Trakl. El viaje es, por sobre todo, una incursión por las múltiples hablas que pululan por bares y callejas, lugares de sombra en los que los poetas y la poesía lentamente son borrados por la niebla del olvido y el indolente abandono. Es una conversación fracasada de sujetos solitarios unidos circunstancialmente por la experiencia de un destino sin destino. Puerto Trakl es, en esta dimensión y en primera instancia, un nütram fallido, protagonizado por sujetos inanes que hacen de la memoria una enfermiza compulsión a la melancolía, a la nostalgia paralizante y autodestructiva, muy lejos de aquella memoria en la que el pasado sigue aconteciendo en un presente pletórico de orígenes conformadores de identidades afirmativas que se erigen a contrapelo de la subalternización y la derrota. El locus Puerto Trakl acontece, entonces, en el tiempo vacío; en un no lugar donde campea la umbría soledad del flâneur en una ex urbe ruinosa en la que pena el deseo siempre insatisfecho de plenitud: lugar desterritorializado, alegórico, hecho de murmullos de sujetos que, como en la Comala de Rulfo, cargan con sus rencores y derrotas sin más horizonte que la permanente invitación a dejarse aturdir por efímeros placeres (el alcohol, por ejemplo) y la transitoria borradura del ser a la que éstos conducen.

Como los no lugares que describe Augé - esas excrecencias de la "sobremodernidad"- Puerto Trakl es un sitio en el que no se crían afectos; se vive aguardando el momento de partir o, en su defecto, no aguardando nada. ${ }^{14}$ Pero si nada se aguarda, si no hay en el horizonte ninguna discontinuidad posible del presente, el no lugar se vuelve "lugar" opresivo que no deja más salida que seguir prisionero en él, y la única manera de tolerarlo sería vivenciarlo precisamente como un no lugar. O mejor: un lugar donde acontece el no lugar, espacio propio de una identidad que se corroe a sí misma en una crepuscular experiencia tal vez no de "sobremodernidad" como lo plantea Augé (2000), sino más bien de modernidad post mortem. Los sujetos de Puerto Trakl viven las ruinas en que se ha convertido aquella modernidad que imaginaba Baudelaire, radicalmente desafiante a la naturaleza pero que, por lo mismo, aunque fuera en el ácido jardín de las flores del mal, prometía una experiencia de eternidad y trascendencia. Ante tal promesa, Georg Trakl es implacablemente escéptico: "Frutas podridas caen de las ramas; / Indecible es el vuelo de las aves; encuentro / Con los moribundos; lo que sigue son años oscuros" (2002:39), dice en uno de sus poemas En clave Huenún, diríamos que ni siquiera la "felicidad" de los "paraísos artificiales" baudelairianos tiene algo que aportar a los poetas que deambulan sin redención posible por bares y callejas de Puerto Trakl: "Todos los caminos desembocan en negra putrefacción" (48), leemos en otro poema del poeta austriaco, verso que bien podría ser una muy exacta descripción de los viajes que

\footnotetext{
${ }^{14}$ La idea de lugar y no lugar está tomada, por cierto, de Marc Augé, en particular de su libro Los "no lugares". Espacios del anonimato (2000).
} 
desembocan en el sombrío Puerto Trakl imaginado por el poeta mapuche huilliche Jaime Huenún que homenajea y ausculta a Trakl.

Vistas así las cosas, el poemario (o poema) Puerto Trakl podría considerarse como el más mestizo de los libros que hasta ahora ha publicado Huenún. El hecho de que en este libro el nütram - en el sentido extendido ya comentado- se vuelva charla trunca, revela que su desplazamiento desde la oralidad mapuche al campo de la escritura poética moderna no se hace sin pérdida del sentido profundamente comunitario y cohesionador de memorias colectivas que caracteriza a este modo indígena de conversar. Lo que resulta en Puerto Trakl es un remedo de nütram, que cancela todo auténtico diálogo, en la medida en que la "comunidad" que habita el Puerto no tiene más destino que carecer de él: literalmente, vive el fin de la historia. La indiferenciada multiplicidad de voces que pululan en las callejas y bares de Puerto Trakl lo constituye como un locus en no diálogo o, a lo más, en diálogo degradado, hecho que viene a reforzar la inmensa soledad del poeta en la sociedad burguesa y la marginalidad rampante de la poesía en los tiempos de una ya post "sobremodernidad", tal como aparece prefigurada en el libro.

Pero si el nütran, que proviene de mundos rurales, al ser trasladado al urbano Puerto Trakl de la poesía se torna incapaz de ejercer su función original de cohesionar/construir memorias comunitarias que evocan hechos y sucesos de un mundo que no se acomoda a los clásicos criterios de realidad y de ficción occidentales, tal fracaso semiótico termina desnudando la miseria de una modernidad ruinosa así como de la poesía que de ella surge. A contracorriente del pesimismo de Georg Trakl, no todos los caminos conducen necesariamente a la putrefacción: el fracaso de la comunicación verdadera en Puerto Trakl, al ser puesto bajo la lupa de una ética/poética reconstituyente de sujetos dañados por la modernidad, da paso a una especie de anagnórisis del sujeto lírico en el sentido que descubre y se convence de que Puerto Trakl no es toda la realidad, que ha de haber otro mundo, otra tierra "mejor que estas colinas". En consecuencia, la tarea que viene es primero salir del opresivo Puerto Trakl, algo que el sujeto efectivamente hace, y arribar alguna vez a esa otra tierra, por caminos que no desemboquen fatalmente en la podredumbre. La poesía de este nuevo viaje es la que ahora toca escribir.

A MOdO DE EPÍLOGO: LO QUE SIGUE ¿SON AÑOS OSCUROS?

Creo ver enmarcado en este reto el largo y persistente trabajo de Huenún destinado a escribir un tercer libro de poemas que haga justicia a la memoria de un pueblo como el mapuche huilliche expoliado por la Corona española primero y por el Estado chileno después; pero que también haga justicia a la poesía, la que por sus ansias permanentes de trascendencia se vuelve un eficaz dispositivo textual de religamiento con las cosas sustanciales del mundo. Se trata de Reducciones, un poemario en el que Huenún ha venido trabajando prácticamente desde hace una 
década, algunos de cuyos poemas, a modo de adelanto, el autor a menudo suele leer en recitales. ${ }^{15}$ No es el momento de comentar un libro en proceso de escritura, pero sí dejar constancia que - al menos en los textos que de este volumen me son familiares - revelan un esfuerzo de Huenún por armar una épica con los fragmentos residuales de una cultura avasallada que no ha de quedarse, tampoco, anclada en el eterno lamento por el pasado perdido, menos en su idealización, y así no clausurar posibilidades de sanar una historia de despojos que, por desgracia, está todavía lejos de terminar.

En un texto publicado en 2000, "Entrada a Chauracahuín”, Huenún nos hace un adelanto de los caminos que vienen después de salir de Puerto Trakl (aunque, en rigor, Ceremonias y Puerto Trakl son también sendos adelantos de una obra mayor en curso que no es sólo Reducciones): denunciar una historia de colonialismo, embrutecimiento y desmemoria de quienes están tanto del lado de los vencedores como del de los perdedores. El escrito apuesta a una cierta promesa de plenitud y restitución de la armonía esencial que ha de concretarse, como vivencia de un modo otro de ser en la modernidad, a través de la recuperación de viejas ceremonias religiosas de mancomunión con la tierra y con los elementos espiritualizados. Mas, el propio texto sugiere que - mientras subsista la desigualdad - tal promesa acaba y acabará siendo un vacío por el que se cuela la frustración, la decadencia, el aturdimiento, la autodestrucción a la manera de otro Puerto Trakl más: el puerto triste y melancólico de los indígenas que no pueden escapar de su propia miseria que de ninguna manera es sólo material.

Oigamos, para terminar, a Jaime Huenún describiendo ese otro Puerto Trakl, metáfora última del fracaso contra el cual la poesía ha de escribir, a fuerza de una potente pero también trabajosa ética de insubordinación, lo que alguna vez tendría que ser una épica de victoria

Insomnes y solemnes, alegres y contritos durante los tres días que celebran nguillatún, los huilliche alzan sus ruegos rodando hacia los viejos arcos de la sangre y la memoria. Huenteao viene a ellos en un soplo de aire frío, en una nube. Invisible se aposenta en el laurel rodeado de pájaros marinos. Contempla el trabajo espiritual de los mortales y escucha sus cantos y plegarias. Vuelve luego, al obscuro roquerío que es su casa y, envuelto por la bruma y el oleaje, duerme y sueña bajo el sol.

Los fieles, mientras tanto, desarman la rueda del ritual y reparten los ramos de canelo que pondrán en las puertas de sus casas. Contra toda brujería servirán esas hojitas, contra todo mal agüero que les dañe los días por venir. Mañana

\footnotetext{
${ }^{15}$ En una conversación que sostuve con Huenún a mediados de octubre de 2010, me ha confidenciado que la escritura de Reducciones ya prácticamente la ha dado por terminada, salvo correcciones menores y detalles de estilo aún pendientes. El lector podrá acceder a un texto de este libro en preparación en EpewFábula. Nuevo imaginario visual de la poesía mapuche contemporánea. Santiago de Chile: Piedra de Sol, 2008.
} 
volverán a los trabajos materiales, a dar un año más de sombra y de sudor a las rojas sementeras. Y a las playas de Maicolpi y Pucatrihue, tras las matas de collofe y de mariscos, nuevamente marcharán.

Y después, hacinados en los buses campesinos, compartiendo el largo viaje con gallinas y corderos, llegarán a la ciudad. Por un día dejarán la tierra del Latué (planta amarga del delirio y de los brujos). En la Feria de Rahue venderán animales y verduras, y los frutos recogidos en el monte. Comerán y beberán en las cantinas aledañas, donde bandas mexicanas cantan cantos de violencia y de dolor. Y en la noche del regreso dormirán frente a los campos, en huilliche borrachera dormirán. (En línea).

Pues bien, Huenún esperaría que la resaca del día siguiente inaugure al fin "la pequeña mañana [que] abre sus puertas" (Puerto Trakl, 53) y los tugurios en los que tantos se deshacen - como diría Quevedo, en tierra, en humo, en polvo, en sombra, en nada — queden para siempre atrás.

\section{BIBLIOGRAFÍA}

Universidad Austral de Chile* Facultad de Filosofía y Humanidades Instituto de Lingüística y Literatura Casilla 567, Valdivia (Chile) changuitad@gmail.com

Anónimo. "Me rebelo contra el rótulo de poesía étnica". Crónica. Consultado: Septiembre 29 del 2010.

Augé, Marc. Los "no lugares". Espacios del anonimato. Una antropología de la sobremodernidad. Trad. Margarita Mizraji. Barcelona: Gedisa, 2000.

Bernaschina, Vicente. "Comunidades provisorias en la poesía de Jaime Huenún". La calle passy 061. Consultado: Octubre 25 del 2010.

Carrasco, Hugo. "Jaime Huenún: hibridez y universalidad", en Crítica situada. El estado actual del arte y la poesía Mapuche. Mabel García Barrera, Hugo Carrasco Muñoz y Verónica Contreras Hauser (Eds.). Temuco: Florencia, 2005:55-66.

Ganderats, Luis Alberto. “Jaime Huenún. Huilliche. Poeta de mil años”. Entrevista a Jaime Huenún. Consultado: Octubre 16 del 2010.

Góngora, María Eugenia; Picón Bruno, Daniela. "Poesía Mapuche: actualidad y permanencias. Entrevista a Jaime Huenún", en Revista Chilena de Literatura. Sección miscelánea (2010):1-10, edición PDF. Consultado: Octubre 6 del 2010.

Huenún, Jaime Luis. "Entrada a Chauracahuín", en Cyberhumanitatis 15. (2000). Consultado: Octubre 25 del 2010.

------ (Ed.). Epu mari ülkatufe ta fachantü. 20 poetas mapuche contemporáneos. Edición biblingüe. Trad. al mapuchezëngun de Víctor Cifuentes. Santiago de Chile: LOM, 2008.

(Comp.). Antología de la poesía indígena latinoamericana. Los cantos ocultos. Santiago de Chile: LOM, 2008. 
------ (Ed. y prologuista). La memoria iluminada. Poesía mapuche contemporánea. Edición bilingüe mapuchezëngun-castellano. Trad. al mapuchezëngun de Víctor Cifuentes. Málaga: Centro de Ediciones de la Diputación de Málaga, 2007.

------ Puerto Trakl. Santiago de Chile: LOM, 2001.

Ceremonias. Santiago de Chile: Universidad de Santiago, 1999.

Martorell, Montserrat; Huenún Jaime. "Escribo para recuperar la memoria". Entrevista a Jaime Huenún, en diario El Periodista, año 6, $\mathrm{N}^{\circ} 155$, viernes 22 de agosto, 2008. Consultado: Septiembre 29 del 2010.

Relmuan Álvarez, María Angélica; Aguilar Lienqueo, María Teresa. Algunos textos orales de Nütram y Prntukun en las comunidades mapuche de Rucapangue y Rapahue de la comuna de Nueva Imperial. Temuco: Instituto de Estudios Indígenas/ Universidad de la Frontera, 1997.

Rojas, Rodrigo. La lengua escorada. La traducción como estrategia de resistencia en cuatro poetas mapuches. Santiago de Chile: Pehuén, 2009.

Said, Edward. El mundo, el texto y el crítico. Trad. Ricardo García Pérez. Buenos Aires: Debate, 2004.

Trakl, Georg. Georg Trakl. Homenaje desde Chile. Comp., y Trad. Sven Olsson-Iriarte. Santiago de Chile: Universitaria, 2002. 